\title{
Murine Monoclonal Antibody 2B8
}

National Cancer Institute

\section{Source}

National Cancer Institute. Murine Monoclonal Antibody 2B8. NCI Thesaurus. Code C2573.

A murine monoclonal antibody directed ag ainst the CD20 phosphoprotein, expressed on the cell surface of normal B-lymphocytes and B-cell lymphomas. 